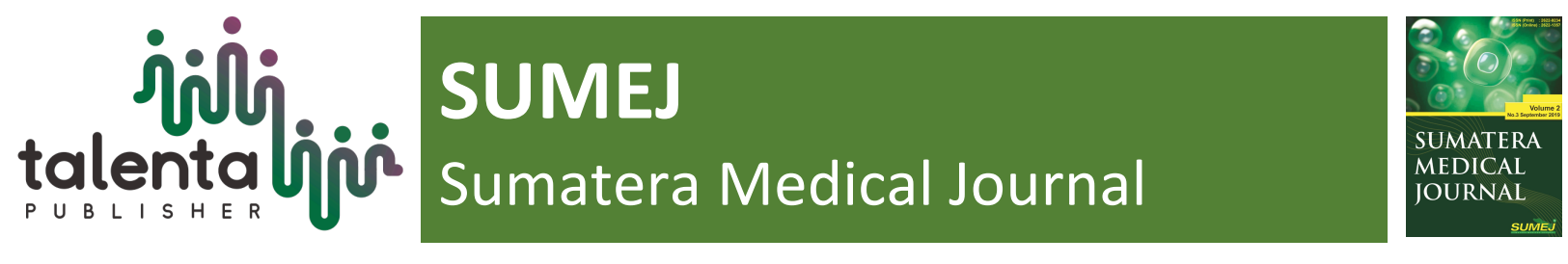

\title{
Exclusive Breastfeeding For Infant Growth and Development in Medan
}

\author{
S. Lumbanraja* \\ Department of Obstetrics and Gynecology, Faculty of Medicine, Universitas Sumatera \\ Utara, Medan, North Sumatera, Indonesia
}

\begin{abstract}
Breast milk is one of the most perfect nutrition to ensure the growth and development of infants in the first 6 months. Exclusive breastfeeding alleged effect on infant growth and development. The purpose of this study was to analyze the influence of exclusive breastfeeding on infant growth and development. This study is a case control study in Sering Primary Health Care Medan in 2014. Anthropometric parameter of subjecs' children were measured and plotted in the WHO graph. Then, subjects were told to undergo a 5 minute interview to ana-lyze the pattern of breastfeeding history. In this study, both infant growth, development, and growth and devel-opment were associated with history exclusive breastfeeding $(\mathrm{p}<0.001)$. Exclusively breastfed infants have good growth and optimal, in contrast to infants who are not breastfed exclusively have poor growth. It was concluded that there was an influence of breastfeeding with infant growth and development.
\end{abstract}

Keyword: exclusive breastfeeding, growth, development

Received 15 August 2019 | Revised 20 September 2019| Accepted 30 September 2019

\section{Introduction}

Improving children's growth and developemnt is an important effort for a better future of Indonesia (Maryunani, 2010, Rochmah et al, 2012, Sriningsih et al, 2011, Saleha, 2009, Hidayanti, 2011). Breast milk is an ideal source of nutrition tailored to the baby's growing needs (Soetjiningsih,1997, Kemenkes, 2007, KPPPA, 2013, Dinkes Propsu, 2011, Roesli, 2004). Breast milk is the most perfect nutrition for ensuring infant growth in the first 6 months. In addition, in the process of breastfeeding the baby will get good phys-ical, emotional, and spiritual development in life (Saleha, 2009).

Exclusive breastfeeding is essential for optimal growth of both physical and mental and infant intelli-gence (Afifah, 2007). Previous study had showed that there was a significant relationship of exclusive breastfeeding with growth in infants aged 3 to 6 months. Babies who were breastfed exclusively would grow in accordance with their normal growth pattern. The latest study from UNICEF also revealed that infant formula-fed data has 25 times higher mor-tality than infants exclusively breast-fed. As exclusive breastfeeding alleged effects on infant growth and de-

*Corresponding author at: Faculty of Medicine, Universitas Sumatera Utara, Medan, Indonesia

E-mail address: sarmalumbanraja@yahoo.com 
velopment (Hidayanti, 2011). The purpose of this study was to analyze the influence of exclusive breastfeeding on infant growth and development.

\section{Method}

Improving children's growth and developemnt is an important effort for a better future of Indonesia (Maryunani, 2010, Rochmah et al, 2012, Sriningsih et al, 2011, Saleha, 2009, Hidayanti, 2011). Breast milk is an ideal source of nutrition tailored to the baby's growing needs (Soetjiningsih,1997, Kemenkes, 2007, KPPPA, 2013, Dinkes Propsu, 2011, Roesli, 2004). Breast milk is the most perfect nutrition for ensuring infant growth in the first 6 months. In addition, in the process of breastfeeding the baby will get good physical, emotional, and spiritual development in life (Saleha, 2009).

Exclusive breastfeeding is essential for optimal growth of both physical and mental and infant intelligence (Afifah, 2007). Previous study had showed that there was a significant relationship of exclusive breastfeeding with growth in infants aged 3 to 6 months. Babies who were breastfed exclusively would grow in accordance with their normal growth pattern. The latest study from UNICEF also revealed that infant formula-fed data has 25 times higher mortality than infants exclusively breast-fed. As exclusive breastfeeding alleged effects on infant growth and development (Hidayanti, 2011). The purpose of this study was to analyze the influence of exclusive breastfeeding on infant growth and development.

\section{Result}

In this study, age range of the subjects with or without exclusive breastfeeding were mostly in 20-35 years old ( $82 \%$ and $96 \%$, respectively), educated until senior high school (62\% and $88 \%$, respectively), and had income above average (66\% and $94 \%)$. However, in subjects with exclusive breastfeeding, mostly was primigravida (52\%), compared to mostly multigravida $(36 \%)$ in subjects without exclusive breastfeeding. The children were majority aged 7-9 months and no difference in gender. This study showed a significant difference of infant growth and development between exclusively and not exclusively breastfed infant (both $\mathrm{p}<0.001$ ). From 50 exclusively breasfed infant, only $8 \%$ infant had short growth compared to $66 \%$ short growth in not exclusively breastfed infant. About $48 \%$ infant that breasfed esxclusively showed tall growth also compared to only $4 \%$ in not exclusively breastfed infant (Table 1). In exclusively breasfed infant, mostly $(94 \%)$ had appropriate development compared to only $10 \%$ in not exclusively breastfed infant. No exclusively breastfed infant had not appropriate development, but $48 \%$ not exclusively breastfed infant showed not appropriate development (Table 2). Overall, this study showed that $96 \%$ infants that were breastfed exclusively had normal growth and development while $72 \%$ that were not breastfed exclusively had abnormal growth and development $(\mathrm{p}<0.001)$ (Table 3$)$. 
Tabel 1. Distribution of infant growth based on the breastfeeding history

\begin{tabular}{|c|c|c|c|c|c|c|c|c|c|}
\hline \multirow{3}{*}{$\begin{array}{l}\text { Breast } \\
\text { feeding }\end{array}$} & \multicolumn{8}{|c|}{ Infant growth } & \multirow{3}{*}{ p-value } \\
\hline & \multicolumn{2}{|c|}{ Short } & \multicolumn{2}{|c|}{ Normal } & \multicolumn{2}{|c|}{ Tall } & \multicolumn{2}{|c|}{ Total } & \\
\hline & $\mathrm{f}$ & $\%$ & $\mathrm{f}$ & $\%$ & $\mathrm{f}$ & $\%$ & $\mathrm{~F}$ & $\%$ & \\
\hline $\begin{array}{l}\text { Exclusi } \\
\text { ve }\end{array}$ & 4 & 8.0 & 22 & 44.0 & 24 & 48.0 & 50 & 100 & \\
\hline $\begin{array}{l}\text { Not } \\
\text { exclusiv } \\
\text { e }\end{array}$ & 33 & 66.0 & 15 & 30.0 & 2 & 4.0 & 50 & 100 & $<0.001$ \\
\hline Total & 37 & $\begin{array}{l}37.8 \\
880\end{array}$ & 37 & 37.0 & 26 & 26.0 & 100 & 100 & \\
\hline
\end{tabular}

Tabel 2. Distribution of infant development based on the breastfeeding history

\begin{tabular}{|c|c|c|c|c|c|c|c|c|c|}
\hline \multirow{3}{*}{$\begin{array}{l}\text { Breast } \\
\text { feeding }\end{array}$} & \multicolumn{8}{|c|}{ Infant development } & \multirow{3}{*}{ p-value } \\
\hline & \multicolumn{2}{|c|}{$\begin{array}{c}\text { Appropri } \\
\text { ate }\end{array}$} & \multicolumn{2}{|c|}{$\begin{array}{l}\text { Underter } \\
\text { mined }\end{array}$} & \multicolumn{2}{|c|}{$\begin{array}{c}\text { Not } \\
\text { appropria } \\
\text { te }\end{array}$} & \multicolumn{2}{|c|}{ Total } & \\
\hline & $\mathrm{f}$ & $\%$ & $\mathrm{f}$ & $\%$ & $\mathrm{f}$ & $\%$ & $\mathrm{f}$ & $\%$ & \\
\hline $\begin{array}{l}\text { Exclusi } \\
\text { ve }\end{array}$ & 47 & 94.0 & 3 & 6.0 & 0 & 0 & 50 & 100 & \\
\hline $\begin{array}{l}\text { Not } \\
\text { exclusiv } \\
\text { e }\end{array}$ & 5 & 10.0 & 21 & 42.0 & 24 & 48.0 & 50 & 100 & $<0.001$ \\
\hline Total & 51 & 51.0 & 24 & 24.0 & 24 & 48.0 & 100 & 100 & \\
\hline
\end{tabular}

Tabel 3. Distribution of infant growth and development based on the breastfeeding history

\begin{tabular}{lccccccc}
\hline & \multicolumn{6}{c}{ Infant Growth and develpment } & \\
\cline { 2 - 6 } $\begin{array}{l}\text { Breastfe } \\
\text { eding }\end{array}$ & Appropriate & \multicolumn{3}{l}{$\begin{array}{l}\text { Undertermi } \\
\text { ned }\end{array}$} & & Total & p-value \\
\cline { 2 - 6 } & $\mathrm{f}$ & $\%$ & $\mathrm{f}$ & $\%$ & $\mathrm{~F}$ & $\%$ & \\
\hline $\begin{array}{l}\text { Exclusi } \\
\text { ve }\end{array}$ & 48 & 96.0 & 2 & 4.0 & 50 & 100 & \\
$\begin{array}{l}\text { Not } \\
\text { exclusiv }\end{array}$ & 14 & 28.0 & 36 & 72.0 & 50 & 100 & \\
e & & & & & & & \\
\hline Total & 62 & 62.0 & 38 & 38.0 & 100 & 100 & \\
\hline
\end{tabular}




\section{Discuccion}

Growth is a major change, the number, size or dimen-sions of cells, organs and individuals measured by weight, length, bone age and metabolic equilibrium (Lidya, 2011, Puskesmas Sering, 2013, PP RI 2012, Ambarwati \& Wulandari, 2008). Growth could measured by length, weight and chemical composition so that growth requires nutrients to produce energy savings, cell division and skeletal usage (Suherni et al, 2009, UU RI 2009, Wulandari \& Handayani, 2011, Muslihatun, 2011, Rukiyah \& Yulianti, 2012). Growth is the basis for assessing the nutritional ade-quacy of infants (Muhammad, 2012, Suprapti, 2013, Soetjiningsih, 1998). In this study, there was a signif-icant effect of exclusive breastfeeding on infant growth $(p<0.001)$. It can be seen clearly that exclu-sively breast-fed infants tend to have good growth, while those not exclusively breastfed tend to have shorter body growth. The result of this study was in corcordance with Lidya (Lidya, 2011)study at Pusk-esmas Karanganyar.

Some researchers analyzed the difference in growth rates between breastfed and formula-fed infants for the first year and were observed later. Birk-beck (1992) showed that breastfed children had better growth parameters. Studies in several developing countries show that the largest causes of nutritional deficiency and growth retardation in children aged 3-15 months are low breastfeeding and poor breastfeed-ing (Lidya, 2012).

The development of child's intelligence was closely related to brain growth. The main factors that affect the child's brain growth was nutrition (Fatmawati, 2010). Exclusive breastfeeding will improve the physical development and perfect brain. In infancy, there was three important substances associated with brain development and infant intelligence, the deco-sahexaenoic acid (DHA) and arachidonic acid (AA) fatty acids, as well as lactose. Both DHA and AA have been shown to help improve vision and some motor responses in infants and toddlers. sIn this study, it was showed that there was a significant ef-fect ofexclusive breastfeeding on infant development $(\mathrm{p}<0.001)$. Babies who got exclusive breastfeeding at 0-6 months of age tend to have appropriate develop-ment (Soetjiningsih, 1998)

Low breastfeeding may be a threat to child growth. In fact, the content of breast milk is rich in caretonoids and selenium, so that breast milk played a role in the baby's immune system to prevent various diseases (Fatmawati, 2010). Each drop of milk also contains minerals and enzymes for the prevention of diseases (Santrock, 2007). According to the ASI Task Force of the Central Board of the Indonesian Pediatricians Association (IDAI), breastfeeding can reduce the per-centage of death to $13 \%$ (Dwiharso, 2010). Infant growth in the work area of Puskesmas often found as much as $38 \%$ in poor category, and from the data if seen that the tendency of infants who are not exclusively breastfed have poorer growth because the ex-clusively breast-fed infants have the best growth. Nu-trition contained in exclusive breastfeeding in accord-ance with the baby's need for growth and they were not present in milk powder or canned milk sold in the market (Prasetyono, 2009).

\section{Conclusion}

It was concluded that there was an influence of breastfeeding with infant growth and development 
[1] Afifah, D.N. 2007. Faktor Yang Berperan Dalam Kegagalan Praktik Pemberian Asi Eksklusif (Studi Kualitatif Di Kecamatan Tembalang, Kota Semarang Tahun 2007), Semarang.

[2] Ambarwati, E.R, Wulandari, D. 2008. Asuhan Kebidanan (Nifas). Cetakan Pertama. Yogyakarta : Mitra Cendikia Offset.

[3] Dinkes Propsu. 2011. Profil Kesehatan Provinsi Sumatera Utara. Medan: Dinas Kesehatan Provinsi Sumatera Utara.

[4] Dwiharso, C.N. 2010. Tingkat Pemberian Asi Eksklusif Di Indonesia Masih Rendah.

[5] Fatmawati, A. 2010. Persepsi Dan Praktek Pemberian Asi Eksklusif. Child Health Services.

[6] Hidayanti, L. 2011. Penurunan Pemberian Asi Eksklusif Sebagai Salah Satu Dampak Paparan Iklan Susu Formula. Prosiding Seminar Nasional Peran Kesehatan Masyarakat Dalam Pencapaian Mdg's Di Indonesia. Bandung: Universitas Siliwangi Tasikmalaya.

[7] Kemenkes RI. 2013. Survei Demografi Dan Kesehatan Indonesia 2012. Kerjasama Bps, Bkkbn, Kemenkes Ri, Dan Usaid.

[8] Kementerian Pemberdayaan Perempuan Dan Perlindungan Anak. 2013. Profil Anak Indonesia 2012. Kerjasama Kementerian Pemberdayaan Perempuan Dan Perlindungan Anak Dengan Badan Pusat Statistik.

[9] Lidya, S. 2011. Hubungan Yang Signifikan Pemberian Asi Eksklusif Dengan Tumbuh Kembang Pada Bayi Umur 3 Sampai 6 Bulan Di Puskesmas Karanganyar. [Tesis].

[10] Maryunani, A. 2010. Ilmu Kesehatan Anak Dalam Kebidanan. Cetakan Pertama. Jakarta: Trans Info Media.

[11] Muhammad, I. 2012. Panduan Penyusunan Karya Tulis Ilmiah Bidang Kesehatan, Cetakan Ketiga. Bandung: Citapustaka Media Perintis.

[12] Muslihatun, W.N. 2010. Asuhan Neonatus Bayi Dan Balita. Cetakan Pertama. Yogyakarta: Fitramaya.

[13] Peraturan Pemerintah RI Nomor 33 Tahun 2012 Tentang Pemberian Air Susu Ibu Eksklusif.

[14] Prasetyono, D.S. 2009. Buku Pintar Asi Eksklusif. Cetakan Pertama. Yogyakarta: Diva Press.

[15] Puskesmas Sering.2013. Laporan Pencatatan Pemberian Asi Eksklusif Pada Bayi 0-6 Bulan Di Wilayah Kerja Puskesmas Sering Bulan Agustus 2013, Medan.

[16] Rochmah, K.M, Vasra, E, Dahliana \& Sumastri, H. 2012. Panduan Belajar Asuhan Neonatus, Bayi, Dan Balita. Cetakan Pertama. Jakarta: EGC

[17] Roesli, U. 2004. Asi Eksklusif. Cetakan Kedua: 7. Jakarta: Trubus Agriwidya.

[18] Rukiyah, A.Y, Yulianti, L. 2012. Asuhan Neonatus, Bayi Dan Anak Balita. Cetakan Pertama. Jakarta: Trans Info Media.

[19] Saleha, S. 2009. Asuhan Kebidanan Pada Masa Nifas. Cetakan Pertama, Jilid I: 28. Jakarta: Salemba Medika.

[20] Santrock, J.W. 2007. Perkembangan Anak. Cetakan Pertama. Jakarta: Erlangga.

[21] Soetjiningsih. 1997. Asi: Petunjuk Untuk Tenaga Kesehatan. Cetakan I: 16. Jakarta: EGC.

[22] Soetjiningsih. 1998. Upaya Peningkatan Kualitas Tumbuh Kembang Anak. Dalam: Gde Ranuh. Tumbuh Kembang Anak. Jakarta: EGC. 
[23] Sriningsih, I. 2011. Faktor Demografi, Pengetahuan Ibu Tentang Air Susu Ibu Dan Pemberian Asi Eksklusif. Jurnal Kesehatan Masyarakat. Kemas; 6(2): 100-106.

[24] Suherni, S, Widyasih, H, Rahmawati, A. 2009. Perawatan Masa Nifas. Cetakan Ketiga. Yogyakarta : Penerbit Fitramaya.

[25] Suprapti. 2013. Pengaruh Pemberian Asi Eksklusif Dan Sikap Ibu Terhadap Pertumbuhan Bayi Di Puskesmas Menganti Gresik.

[26] Undang-Undang Republik Indonesia Nomor 36 Tahun 2009 Tentang Kesehatan.

[27] Wulandari, S.R, Handayani, S. 2011. Asuhan Kebidanan Ibu Masa Nifas. Cetakan Pertama, Yogyakarta : Gosyen Publishing 